http://dx.doi.org/10.18778/1509-877X.2018.01.03

\title{
ZMIANY W PODATKU AKCYZOWYM
}

Streszczenie. Najistotniejsze zmiany w podatku akcyzowym, pod hasłem uproszczeń i ułatwień prowadzenia działalności gospodarczej w zakresie wyrobów akcyzowych, to przede wszystkim: zerowa stawka dla gazu ziemnego CNG i LNG przeznaczonego do napędu silników spalinowych, wyłączenie z zakresu definicji ubytków strat powstających podczas produkcji piwa i wyrobów winiarskich, zastąpienie papierowego dokumentu dostawy - dokumentem w postaci elektronicznej (e-DD), wprowadzenie na terytorium kraju możliwości podziału przemieszczenia w przypadku wyrobów energetycznych przemieszczanych transportem kolejowym (spliting).

Zmiany te stanowią ułatwienia i uproszczenia dla prowadzenia działalności, system poboru podatku akcyzowego dzięki systemowym rozwiązaniom okazał się bowiem najszczelniejszym systemem poboru podatków na tle przyrostów uzyskiwanych w innych podatkach, który nie wymaga zmian systemowych.

Słowa kluczowe: akcyza, eDD, ubytki, stawki

1. WPROWADZENIE

System poboru podatku akcyzowego dzięki systemowym rozwiązaniom okazał się najszczelniejszym systemem poboru podatków na tle przyrostów uzyskiwanych w innych podatkach. Jest to jednak system, który musi się rozwijać wraz z rozwojem gospodarki, nowymi technologiami produkcji i dystrybucji oraz nowymi wymaganiami wynikającymi z regulacji unijnych.

* Doradca podatkowy, wspólnik i partner w BBGTAX kancelaria podatkowa, e-mail: kancelaria@bbgtax.pl 
20 lipca 2018 r. Sejm RP uchwalił nowelizację ustawy o podatku akcyzowym $^{1}$ (dalej: u.p.a.) pod hasłem uproszczeń i ułatwień prowadzenia działalności gospodarczej w zakresie wyrobów akcyzowych przez zmniejszenie obciążeń administracyjnych dla przedsiębiorców, ograniczenie ponoszonych przez nich kosztów oraz czasochłonności obsługi podmiotów przez organy podatkowe.

Ustawa ta wprowadza przede wszystkim:

- zerową stawkę dla gazu ziemnego CNG i LNG przeznaczonego do napędu silników spalinowych;

- wyłączenie z zakresu definicji ubytków wyrobów akcyzowych strat powstających podczas produkcji piwa i wyrobów winiarskich;

- zastąpienie papierowego dokumentu dostawy - stosowanego przy przemieszczaniu poza procedurą zawieszenia poboru akcyzy wyrobów zwolnionych od akcyzy ze względu na ich przeznaczenie oraz wyrobów energetycznych opodatkowanych zerową stawką akcyzy ze względu na ich przeznaczenie - dokumentem w postaci elektronicznej (e-DD);

- wprowadzenie na terytorium kraju możliwości podziału przemieszczenia w przypadku wyrobów energetycznych przemieszczanych transportem kolejowym z zastosowaniem procedury zawieszenia poboru akcyzy w systemie EMCS.

2. WPROWADZENIE ZEROWEJ STAWKI AKCYZY DLA GAZU ZIEMNEGO O KODACH CN 271111 OO I 27112100 PRZEZNACZONEGO DO NAPĘDU SILNIKÓW SPALINOWYCH

Gaz ziemny jest paliwem zawierającym ponad 90\% metanu, które w postaci sprężonej (CNG) lub skroplonej (LNG) nadaje się do napędzania niskoemisyjnych pojazdów, np. komunikacji miejskiej w centrach dużych miast. Gaz ziemny jest jednym z najbardziej ekologicznych i ekonomicznych paliw silnikowych. CNG umożliwia ograniczenie emisji zanieczyszczeń spalin, wyeliminowanie emisji substancji rakotwórczych, 99-procentową redukcję zadymienia i smogu, 40-procentowe obniżenie poziomu hałasu. Gaz ziemny (metan) zawiera na jednostkę energetyczną mniej związków węgla niż jakiekolwiek paliwa kopalne. Stąd emisja zarówno CO, jak i $\mathrm{CO}_{2}$ jest mniejsza dla tej technologii niż np. dla benzyny czy ON.

${ }^{1}$ Ustawa z dnia 20 lipca 2018 r. o zmianie ustawy o podatku akcyzowym oraz ustawy - Prawo celne (Dz.U. z 2018 r., poz. 1697). 
Zgodnie z uzasadnieniem do nowej ustawy obecnie cena gazu CNG to około $3,30 \mathrm{zł} / \mathrm{m}^{3}$, w tym podatek akcyzowy zawarty w cenie to 33 gr. Koszt dla budżetu po wprowadzeniu zerowej stawki akcyzy, biorąc pod uwagę roczną konsumpcję tego paliwa, wyniesie więc około 6,6 mln zł. Z kolei roczne zużycie gazu LNG to około $2,7 \mathrm{mln} \mathrm{kg}$, co powoduje, że wpływy z tytułu podatku akcyzowego wynoszą około 1,8 mln zł. Łącznie obniżenie akcyzy dla gazu CNG i LNG do 0 zł spowoduje spadek wpływów budżetowych z tego tytułu o około 8,4 mln zł.

Ustawa zmieniająca wprowadza zerową stawkę akcyzy dla gazu ziemnego o kodach CN 27111100 i 27112100 przeznaczonego do napędu silników spalinowych, co wymaga dodania nowego przepisu w brzmieniu zaproponowanym w art. 89 ust. 1 pkt 12 lit. aa u.p.a. W obecnym stanie prawnym gaz ziemny przeznaczony do napędu silników spalinowych jest opodatkowany, w zależności od jego stanu skupienia, stawką akcyzy w wysokości:

- skroplony gaz ziemny (LNG) - $670 \mathrm{zl} / 1000 \mathrm{~kg}$,

- sprężony gaz ziemny (CNG) - 10,54 zł/GJ.

Wprowadzenie zerowej stawki akcyzy na gaz LNG i CNG będzie bodźcem do rozwoju infrastruktury gazowej w kraju, który oprócz oczywistych korzyści ekologicznych pozytywnie wpłynie na realizację rządowej polityki gazyfikacji kraju. Szersze niż dotychczas wykorzystanie LNG i CNG stanowi także element dywersyfikacji paliw napędowych, a zatem przyczynia się do zwiększania bezpieczeństwa transportu w kraju.

Proponowane obniżenie stawki akcyzy może stanowić pomoc publiczną dla przedsiębiorstw wykorzystujących lub sprzedających gaz CNG i LNG. Mimo że podatek akcyzowy jest w dużym stopniu zharmonizowany na poziomie unijnym, nie oznacza to automatycznie, że każde zwolnienie lub obniżenie akcyzy wykracza poza zakres zasad pomocy publicznej. Obniżenie akcyzy nie stanowiłoby pomocy publicznej, tylko jeżeli danego środka nie można przypisać państwu, tj. gdy państwo członkowskie jest zobowiązane do jego wdrożenia na mocy aktu prawodawstwa unijnego bez żadnej swobody oceny. Natomiast jeżeli państwo członkowskie ma swobodę przyjęcia środków dopuszczonych przez prawo unijne (np. obniżenie akcyzy na niektóre towary), to ich wprowadzenie może nastąpić jedynie w zgodzie z przepisami o pomocy publicznej. 


\section{ZMiANY DOTYCZĄCE UbYTKóW}

Obecnie straty piwa i wyrobów winiarskich określane są na poszczególnych etapach produkcji. W przypadku przekroczenia określonych norm należy od tych strat zapłacić podatek akcyzowy. Na gruncie polskich przepisów akcyzowych ubytki wyrobów akcyzowych są rozliczane na podstawie norm ustalonych $\mathrm{w}$ drodze decyzji właściwego naczelnika urzędu skarbowego, zgodnie z art. 85 ust. 1 pkt 1 albo ust. 2 pkt 1 lit. a u.p.a., albo określone w przepisach wydanych na podstawie art. 85 ust. 7 u.p.a. Normy dopuszczalnych ubytków wyrobów akcyzowych są ustalane przez organy podatkowe do wysokości nieprzekraczającej maksymalnych norm wskazanych w przepisach wykonawczych do ustawy.

Oznacza to, że organy podatkowe nie mogą przyznać norm ubytków wyższych niż normy maksymalne określone w rozporządzeniu, nawet gdyby rzeczywiste straty technologiczne uzasadniały taką decyzję. Proponowane wyłączenie z zakresu definicji ubytków wyrobów akcyzowych strat powstających podczas produkcji piwa i wyrobów winiarskich spowoduje brak konieczności ich mierzenia na każdym etapie produkcji. W przypadku piwa i wyrobów winiarskich zmiany ograniczą zakres określenia norm do sfery magazynowania i przemieszczania. Natomiast proponowane zwolnienie od akcyzy ubytków wyrobów akcyzowych przekraczających maksymalny poziom norm do wysokości równej rzeczywistym stratom, jeżeli podmiot udowodni ich naturalny charakter wynikający z właściwości wyrobów, pozwoli w praktyce na udowadnianie wyższych niż określone w decyzji norm ubytków.

Regulacje wprowadzają do polskich przepisów akcyzowych mechanizm, który umożliwi podatnikowi wykazanie, że rzeczywiste ubytki wyrobów akcyzowych przekraczające maksymalny poziom określony na podstawie przepisów mają charakter naturalny. Jednym z głównych celów dyrektywy Rady 2008/118/WE z dnia 16 grudnia 2008 r. w sprawie ogólnych zasad dotyczących podatku akcyzowego, uchylającej dyrektywę 92/12/EWG ${ }^{2}$ (dalej: dyrektywa), jest zapewnienie jednolitego systemu opodatkowania akcyzą we wszystkich państwach członkowskich Unii Europejskiej (UE), opartego na zasadzie opodatkowania konsumpcji. Cel ten jest zawarty w art. 7 ust. 1 dyrektywy, w świetle którego podatek akcyzowy staje się wymagalny w momencie dopuszczenia do konsumpcji. Zgodnie z art. 7

${ }^{2}$ Dz.Urz. UE L 9 z dnia 14 stycznia 2009 r. 
ust. 2 lit. a dyrektywy dopuszczenie do konsumpcji oznacza opuszczenie procedury zawieszenia poboru akcyzy w odniesieniu do wyrobów akcyzowych, w tym opuszczenie niezgodne z przepisami. Zgodnie z art. 7 ust. 4 dyrektywy za dopuszczenie do konsumpcji nie uważa się jednak całkowitego zniszczenia ani nieodwracalnej utraty wyrobów akcyzowych objętych procedurą zawieszenia poboru akcyzy, jeżeli zniszczenie lub utrata wynikają m.in. z właściwości tych wyrobów - tzw. ubytki naturalne.

4. ZastąPiEnie Papierowego doKumentu dostawy STOSOWANEgo PRZY PRZEMIESZCZANIU POZA PROCEDURĄ ZAWIESZENIA POBORU AKCYZY WYROBÓW ZWOLNIONYCH OD AKCYZY ZE WZGLĘDU NA ICH PRZEZNACZENIE ORAZ WYROBÓW ENERGETYCZNYCH OPODATKOWANYCH ZEROWĄ STAWKĄ AKCYZY ZE WZGLĘDU NA ICH PRZEZNACZENIE - DOKUMENTEM W POSTACI ELEKTRONICZNEJ (E-DD)

$\mathrm{Na}$ podstawie obecnych przepisów akcyzowych dokumentowanie przemieszczeń wyrobów akcyzowych zwolnionych od akcyzy ze względu na ich przeznaczenie oraz wyrobów akcyzowych wymienionych w załączniku nr 2 do u.p.a. opodatkowanych zerową stawką od akcyzy ze względu na ich przeznaczenie za pomocą dokumentu dostawy jest jednym $z$ warunków stosowania zwolnienia tych wyrobów od podatku akcyzowego oraz zerowej stawki podatku akcyzowego. Wzór i sposób stosowania dokumentu dostawy określa obecnie Rozporządzenie Ministra Finansów z dnia 22 grudnia 2015 r. w sprawie dokumentu dostawy, warunków i sposobu zwrotu wyrobów akcyzowych objętych zwolnieniem od akcyzy ze względu na ich przeznaczenie oraz środków skażających alkohol etylowy ${ }^{3}$. Zgodnie z tym rozporządzeniem dokument dostawy wystawiają takie podmioty, jak: podmiot prowadzący skład podatkowy, podmiot pośredniczący, zarejestrowany odbiorca, podmiot zużywający, pośredniczący podmiot węglowy, finalny nabywca węglowy. Dokument dostawy jest wystawiany w trzech, dwóch lub w jednym egzemplarzu, w zależności od rodzaju przemieszczenia i osób biorących w nim udział. Podmioty wystawiające dokumenty dostawy są obowiązane do sporządzania kwartalnych zestawień wystawionych dokumentów dostawy, które przekazują właściwemu naczelnikowi urzędu skarbowego w terminie do 25. dnia miesiąca następującego po kwartale, którego dotyczy zestawienie.

\footnotetext{
${ }^{3}$ Dz.U. z 2015 r., poz. 2285 ze zm.
} 
Zmiana u.p.a. ma na celu zastąpienie wystawianego papierowego dokumentu dostawy stosowanego obecnie dla dokumentowania przemieszczeń w kraju poza procedurą zawieszenia poboru akcyzy:

1) wyrobów akcyzowych zwolnionych od akcyzy ze względu na ich przeznaczenie oraz

2) wyrobów akcyzowych wymienionych w załączniku nr 2 do u.p.a., opodatkowanych zerową stawką od akcyzy ze względu na ich przeznaczenie

- elektronicznym dokumentem dostawy (określanym w projekcie jako e-DD), który będzie generowany w Systemie EMCS PL2, wykorzystywanym obecnie do obsługi przemieszczeń wyrobów akcyzowych w procedurze zawieszenia poboru akcyzy.

Ustawa zmieniająca przewiduje:

1) rozbudowę systemu EMCS PL2 w celu stworzenia rozwiązań podobnych do tych stosowanych przy przemieszczaniu wyrobów akcyzowych w procedurze zawieszenia poboru akcyzy;

2) zastąpienie dokumentu dostawy w postaci papierowej - elektronicznym dokumentem e-DD, który będzie generowany w Systemie EMCS PL2 - systemie wykorzystywanym obecnie jedynie do przemieszczania wyrobów akcyzowych w procedurze zawieszenia poboru akcyzy;

3) stosowanie e-DD (szczegółowy zakres danych, które powinny być zawarte w e-DD, zostanie określony w rozporządzeniu wykonawczym do ustawy). E-DD będzie zawierał dodatkowe elementy/pola, takie jak: TIN podmiotu czy nr GRN zabezpieczenia akcyzowego, niezbędne dla elektronicznej weryfikacji podmiotu generującego e-DD w Systemie EMCS PL2 oraz weryfikacji zabezpieczenia akcyzowego, które musi złożyć podmiot wysyłający wyroby zwolnione ze względu na ich przeznaczenie przed dokonaniem ich przemieszczania. W tym celu System EMCS PL2 będzie współpracował jednocześnie z Systemem OSOZ2 (Ogólnopolski System Obsługi Zabezpieczeń 2), który będzie dokonywać automatycznej obsługi zabezpieczeń akcyzowych wymaganych w przypadku przemieszczenia wyrobów zwolnionych (z wyłączeniem wyrobów akcyzowych opodatkowanych zerową stawką akcyzy, które nie podlegają zabezpieczeniu akcyzowemu);

4) potwierdzanie przez podmiot odbierający odbioru wyrobów zwolnionych lub opodatkowanych zerową stawką akcyzy dokumentem generowanym w Systemie EMCS PL2, określanym jako raport odbioru (RoR). W przypadku podmiotów odbierających niebędących użytkownikami 
Systemu EMCS PL2 raport odbioru będzie sporządzał podmiot wysyłający, na podstawie potwierdzenia odbioru dokonanego przez podmiot odbierający;

5) dokumentowanie przy wykorzystaniu e-DD nie tylko dostaw na terytorium kraju wyrobów zwolnionych oraz opodatkowanych zerową stawką akcyzy, ale także ich importu. W przypadku importu wyroby nie będą przemieszczane na podstawie e-DD, ale e-DD będzie sporządzany w celach dokumentacyjnych w terminie 15 dni od dnia dopuszczenia do obrotu wyrobów. W związku ze specyfiką obrotu zwolnionymi od akcyzy paliwami lotniczymi oraz gazem płynnym LPG - przewidziano szczególne regulacje w zakresie dokumentowania tego obrotu z wykorzystaniem Systemu.

\section{WPROWADZENIE NA TERYTORIUM KRAJU MOŻLIWOŚCI PODZIAŁU PRZEMIESZCZENIA W PRZYPADKU WYROBÓW ENERGETYCZNYCH} PRZEMIESZCZANYCH TRANSPORTEM KOLEJOWYM Z ZASTOSOWANIEM PROCEDURY ZAWIESZENIA POBORU AKCYZY w SySTEMIE EMCS

Przepis art. 23 dyrektywy 2008/118/WE ${ }^{4}$ przewiduje, że organy państwa członkowskiego wysyłki mogą, na warunkach określonych przez to państwo członkowskie, zezwolić wysyłającemu na dokonanie podziału przemieszczania wyrobów energetycznych w procedurze zawieszenia poboru akcyzy na co najmniej dwa przemieszczenia, pod warunkiem że:

1) całkowita ilość wyrobów akcyzowych nie ulegnie zmianie;

2) podział nastąpi na terytorium państwa członkowskiego, które zezwoli na taką procedurę;

3) właściwe organy tego państwa członkowskiego zostaną poinformowane o miejscu, w którym nastąpi podział.

Regulacja ta, mająca charakter fakultatywny, nie była do tej pory przewidziana w polskim porządku prawnym. Biorąc jednak pod uwagę występujące często w transporcie kolejowym przypadki, że część wagonów kolejowych, którymi przemieszczane są wyroby energetyczne w procedurze zawieszenia poboru akcyzy, $\mathrm{z}$ różnych przyczyn (przede wszystkim z powodu awarii) nie może dotrzeć do miejsca przeznaczenia wskazanego w e- $\mathrm{AD}$, zdecydowano o wprowadzeniu w przepisach krajowych takiej regulacji (w dodanym art. 41i u.p.a.). Ze względu na zwiększone ryzyko nieprawidłowości w przypadku podziału przemieszczania wprowadzona regulacja odnosi się tylko do wyrobów energetycznych przewożonych transportem

\footnotetext{
${ }^{4}$ Dz.Urz. UE L 9 z dnia 14 stycznia 2009 r.
} 
kolejowym z zastosowaniem procedury zawieszenia poboru akcyzy w Systemie EMCS. Regulacja ta nie obejmuje wyrobów energetycznych objętych zwolnieniem od akcyzy wynikającym $\mathrm{z}$ art. 31 ust. 1 u.p.a., przemieszczanych w Systemie EMCS z zastosowaniem świadectwa zwolnienia, o którym mowa w Rozporządzeniu Komisji (WE) nr 31/96 z dnia 10 stycznia 1996 r. w sprawie świadectwa zwolnienia z podatku akcyzowego ${ }^{5}$.

Przedmiotowa, korzystna dla podmiotów regulacja umożliwi dokonywanie na terytorium kraju podziału rozpoczętego już przemieszczania, odbywającego się na podstawie jednego e-AD na dwa lub więcej przemieszczeń, z czego każde będzie się odbywać na podstawie nowo utworzonego e-AD. W celu dokonania podziału podmiot wysyłający będzie musiał poinformować o tym fakcie naczelnika urzędu celno-skarbowego właściwego ze względu na miejsce dokonywania podziału oraz wysłać do Systemu projekt powiadomienia o podziale przemieszczenia. Jeżeli projekt powiadomienia będzie zawierał niekompletne lub nieprawidłowe dane, z Systemu zostanie automatycznie wysłana informacja o błędach. W przypadku przyjęcia przez System powiadomienia dla podzielonych przemieszczeń zostaną utworzone nowe e-AD, które zastąpią pierwotnie wystawiony e-AD. W wyniku podziału przemieszczenia zepsute wagony będą mogły być formalnie np. zawrócone do składu podatkowego podmiotu wysyłającego jako część podzielonego przemieszczenia, a podmiot odbierający będzie mógł odebrać tylko część pierwotnie wysłanych wyrobów i potwierdzić ich odbiór zgodnie z nowym e-AD. Po dokonaniu podziału przemieszczenia podmiot wysyłający będzie mógł dokonać zmiany miejsca przeznaczenia wyrobów lub dokonać kolejnego podziału przemieszczenia. Zabezpieczenie akcyzowe złożone $\mathrm{w}$ związku z przemieszczeniem na podstawie pierwotnego e-AD nie zostanie w związku z podziałem zwolnione i na nowo obciążone. Zabezpieczenie to zostanie zwolnione dopiero po zakończeniu wszystkich przemieszczeń dokonanych na podstawie nowych e-AD wygenerowanych w związku z podziałem.

Podmioty wysyłające $\mathrm{z}$ innych państw członkowskich będą mogły dokonywać podziału przemieszczenia na terytorium kraju, jeżeli w Systemie EMCS, który funkcjonuje w ich państwie członkowskim, przewidziano funkcjonalności umożliwiające dokonanie podziału przemieszczenia. Zgodnie z art. 23 dyrektywy 2008/118/WE państwa członkowskie, które zezwalają na podział, mają obowiązek poinformować Komisję, czy

${ }^{5}$ Dz.Urz. UE L 8 z dnia 11 stycznia 1996 r. 
i na jakich warunkach zezwalają na dokonanie podziału przemieszczenia, a Komisja przekazuje te informacje pozostałym państwom członkowskim.

14 grudnia 2018 r. Sejm uchwalił ustawę zmieniającą ustawę o zmianie ustawy o podatku akcyzowym oraz ustawy - Prawo celne przesuwającą o rok obligatoryjność stosowania elektronicznego dokumentu dostawy. W konsekwencji mamy do czynienia $\mathrm{z}$ dualizmem dokumentacyjnym $\mathrm{w}$ obrocie wyrobami zwolnionymi $\mathrm{z}$ akcyzy ze względu na przeznaczenie oraz opodatkowanymi zerową stawką, bo można stosować jako dokument towarzyszący zarówno elektroniczny dokument dostawy, jak i dotychczas stosowany dokument dostawy w wersji papierowej. Obecnie Minister Finansów rozważa przedłużenie tego stanu rzeczy o kolejny rok.

6. WNIOSKI

Zmiany w podatku akcyzowym to naturalna konsekwencja rozwoju tego podatku wynikająca z postępu technologicznego (rozwój dokumentów elektronicznych), z dobrej kondycji budżetu państwa (zerowa stawka na gaz CNG do napędu) oraz z analizy ryzyka (odejście od opodatkowania i rozliczania ubytków produkcyjnych w piwie i winie).

W przyszłości warto uwzględnić zmiany w systemie opodatkowania i oznaczania wyrobów tytoniowych, który był dostosowany do corocznych zmian stawek podatku akcyzowego na te wyroby. Obecnie przy braku takich zmian należy przeanalizować kwestię stosowania mechanizmu ograniczającego tworzenie zapasów, a także uaktualnienia mechanizmu minimalnej stawki.

\section{Changes in excise tax}

Summary. The most important changes in the excise duty, under the slogan of simplifications and facilitation of running a business in the field of excise goods, are primarily: zero rate for CNG and LNG natural gas intended for the drive of internal combustion engines, exclusion from the scope of the definition of loss of losses arising during the production of beer and wine products, replacement of a paper delivery document - a document in electronic form (e-DD), introduction of the possibility of dividing shipments in the territory of the country in the case of energy products transported by rail (spliting).

These changes are simplifications for running the business, because the system of collecting excise duty, thanks to systemic solutions, has proved to be the most efficient tax collection system against the background of increments obtained in other taxes, which does not require system changes.

Keywords: excise duties, eDD, losses, tax rates 